\title{
Molecular cytogenetical effects of some mycotoxins to chromosomes of Triticum durum using RAPD-PCR fluorescence in situ hybridization
}

\author{
Magdy Hussein Abd El-Twab ${ }^{1}$, Mohammed Abdel Hakeem Mahmoud ${ }^{2}$, \\ Rasha Kamal Helmey and Ezzat Mahmoud Fadl-Allah
}

Department of Botany and Microbiology, Faculty of Science and ${ }^{2}$ Department of
Genetics, Faculty of Agriculture, Minia University, El-Minia City, Egypt

${ }^{1}$ Author for corrspondence (magdyh2@yahoo.com)

Received February 17, 2009; accepted March 27, 2009

\begin{abstract}
PCR-amplified DNA using the random primer OPB-06 was used as a probe for Fluorescence in situ hybridization (FISH). Signals of hybridized sites were observed in both interphase and metaphase plates after hybridization. The FISH signals of the metaphase chromosomes were confirmed as two yellow-color signals hybridized with the probe on two adjacent loci at interphase of the control plates. FISH analysis of the metaphase plates of $25 \mu \mathrm{g} / \mathrm{ml}$ deoxynivlenol (DON) and aflatoxin $\mathrm{B}_{1}\left(\mathrm{AFB}_{1}\right)$ treated plants revealed $85.7 \%$ and $89.3 \%$, respectively had no signals. Of the metaphase plates of plants treated with $\mathrm{AFB}_{1}, 3.6 \%$ had one terminal signal while $7.1 \%$ revealed two signals and no signals were observed in $89.3 \%$ plates. Regarding the interphase nuclei, only one signal was observed in $42.1 \%$ of the plates where two signals were observed in $57.8 \%$ interphase plates. $10.7 \%$ metaphase plates of plants treated with DON had one terminal signal while $3.6 \%$ exhibit two signals and no signals were observed in $85.7 \%$ plates of metaphase. $44.1 \%$ of the interphase nuclei had one signal while $53.2 \%$ plates reveal two signals and four signals were observed in $2.7 \%$ interphase nuclei. Disappearance of FISH signals in some metaphase plates of plants treated with the two investigated toxins indicates the toxigenic effect of these mycotoxins on metaphase chromosomes of wheat.
\end{abstract}

KEYWORDS: $\mathrm{AFB}_{1}$, DON, FISH, RAPD, Triticum durum.

Mycotoxins are secondary metabolic products from moulds which can grow on the plant either in the field or during storage (El-Naghy et al. 1991) and are potentially toxic for human beings and animals. A few mycotoxins are recognized as major food safety hazards and major mycotoxins in food and feed including aflatoxins, fumonsins, ochratoxinA, trichothecenes and zearalenone (Miller et al. 2001). Some of these mycotoxins are associated with chronic syndromes such as carcinogenicity and immunosuppression. On the other hand, few studies have been performed on the effect of mycotoxins on plant cell (Fadl-Allah 1987; Fadl-Allah 1998; Badr et al. 2002; El-Naghy et al. 1999; Fadl-Allah et al. 2007; Fadl-Allah and Abdel-Rahem 1991; Mahmoud et al. 2008). Aflatoxins represent a group of mycotoxins produced by many strains of Aspergillus flavus and Aspergillus parasiticus; in particular, Aspergillus flavus is a common contaminant in agriculture. The carcinogenic properties of aflatoxins have been extensively studied, and great insight has been gained concerning aflatoxin modes of action, levels of food contamination and proposed importance as risk factors for primary liver cancer in humans (Busby and Wogan 1984 ; Wogan 1992). Aflatoxin $\mathrm{B}_{1}$ is the most potent natural carcinogen known (Squire 1981) and is usually the major aflatoxin produced by toxigenic strains. In 1993, the International Agency for Research on Cancer (IARC) reported that there is sufficient evidence to classify aflatoxin $\mathrm{B}_{1}$ the most potent fraction of aflatoxins as Group 1 of carcinogens in humans 3 . Morover, various studies in different chemically exposed animal species have demonstrated the potent hepatocarcinogenic effect of aflatoxins (Wogan 1992;
Robens and Richard 1992). The mutagenicity of aflatoxin $\mathrm{B}_{1}$ to animals and humans is believed to involve oxidative activation by a cytochrome $\mathrm{P} 450$, in the liver and the kidney. An epoxide is created at the 8,9 position that reacts with the N7-guanine residues of DNA, causing mutations in the tumor repressor gene p53 (Minto and Townsend 1997). In wheat, aflatoxin $B_{1}$ induces alterations in DNA profiles as reported by Fadl-Allah et al. (2007). Shen and Ong (1996) summarized that the genotoxic effects of $\mathrm{AFB}_{1}$ have been studied with respect to : (i) AFB1-DNA adduct formation; (ii) AFB1 induced gene mutations; (iii) $\mathrm{AFB}_{1}$ induced chromosomal damage; (iv) AFB1 induced DNA synthesis and DNA repair inhibition and (v) AFB1 induced in vitro cell transformation. Unlike aflatoxins, Trichthecenes can act immediately upon contact. The trichothecenes are a group of 182 structurally related metabolites produced by a number of fungal genera, including Fusarium, Stachybotrys, and other molds (Scott 1989; Grove 1993 1996). The term trichothecene is derived from trichothecin, which was the one of the first members of the family identified. Diacetoxyscirpenol, deoxynivalenol and T-2 mycotoxins are common trichothecenes produced by Fusarium species which was reported to be one of the dominant fungi in wheat kernels (Hocking et al. 2006). Deoxynivalenol is one of the most common mycotoxins found in grains (i.e. barley, corn, rye, safflower seeds, wheat) and mixed feeds. The consumption of these grains contaminated with mycotoxins can result in alimentary hemorrhage and vomiting; direct contact causes dermatitis (Beasley 1989; Joffe 1986; Marasas et al. 1984) and when ingested in high doses by agricultural animals, it causes nausea, 
vomiting, and diarrhea (Miller et al. 2001). DNA synthesis is strongly inhibited in various types of animal cells that are exposed to trichothecenes (McLauglin et al. 1977). In mice or rat treated with trichothecene mycotoxins, DNA synthesis was suppressed in all tissues studied, although to a lesser degree than protein synthesis (Thompson and Wannemacher 1990). The pattern by which DNA synthesis is inhibited by trichothecenes is consistent with the primary effect of these toxins on protein synthesis. It has been found that, trichothecenes are extremely potent inhibitors of eukaryotic protein synthesis as different trichothecenes interfere with initiation, elongation, and termination stages. Trichodermin was the first trichothecene shown to inhibit peptidyl transferase activity (Stafford and McLaughlin 1973 and Wei et al. 1974). Subsequently, it would appear that, all trichothecenes inhibit peptidyl transferase by binding to the same ribosome-binding site (Feinberg and McLaughlin 1989).

The cytotoxic effects of DON were also studied by Packa (1991). Who recorded a decrease in the mitotic index in root- tip cells of germinated caryopsis of rye and wheat plant, and scored chromosomal abnormalities in dividing cells. Similar effects of DON were observed on dividing onion (Allium cepa L.) root- tip cells (Masood et al. 1993).

In situ hybridization is a valuable method for studying the chromosomal distribution of DNA sequences and copy numbers at different sites and to follow the changes in their physical organization in the genome (Harrison and Heslop-Harrison 1995; Kondo et al. 1996; Abd E1-Twab and Kondo 2007). Fluorescence in situ hybridization (FISH) is an excellent tool for chromosome identification and studies of genome introgression (Jiang and Gill 1994; Abd El-Twab and Kondo 2007, 2008).

The objective of the present work was to (1) confirm the involvement of other possible mechanisms in mycotoxins induce toxicity, (2) determine the number and location of the RAPD-PCR labeled probe by FISH on the chromosomes of the investigated control and treated plants and (3) inferring changes of RAPD-PCR DNA fragments by FISH on the chromosomes of the treated plants after $\mathrm{AFB}_{1}$ and $\mathrm{DON}$ stress.

\section{Materials ANd Methods}

Plant materials Grains of Triticum durum cv. 'BeniSweif 1' considered as one of the most important crop in Egypt were kindly obtained from Seds Research Center Beni-Sweif Governorate, Egypt.

Toxins Pure toxins such as deoxynivalenol and aflatoxin $\mathrm{B}_{1}$ used were obtained from Sigma Chemical Company. Deoxynivalenol (DON) was dissolved in ethyl acetate while aflatoxin $\mathrm{B}_{1}$ was dissolved in ethyl alcohol and the required dilutions $(25 \mu \mathrm{g} / \mathrm{ml})$ were prepared with sterile distilled water.
Germination For surface sterilization, similar mature grains of wheat were selected, washed with ethylalcohol $70 \%+\mathrm{H}_{2} \mathrm{O}_{2}$ for $3 \mathrm{~min}$, rinsed thoroughly in sterile distilled water and allowed to dry on sterile filter paper. Surface sterilized grains were soaked in sterile water for $24 \mathrm{~h}$ and then soaked in the appropriate concentrations of toxins for $24 \mathrm{~h}$. As the control, grains were soaked in sterile distilled water free of toxin, for the same time. Grains germinated and grew in Petri dishes at $25^{\circ} \mathrm{C}$ for $48 \mathrm{~h}$.

Chromosome preparations Growing root tips were collected and pretreated in $0.5 \%$ colchicine at room temperature for $2 \mathrm{~h}$. They were fixed in 3:1 ethanol and acetic acid at room temperature for $24 \mathrm{~h}$. Fixed roots were excised and washed thoroughly in distilled water to remove the fixative. Roots were hydrolyzed by using enzymatic mixture of $2 \%$ cellulose and $3 \%$ pectyolase. They were incubated at $37^{\circ} \mathrm{C}$ for $50 \mathrm{~min}$, then washed in distilled water to remove the enzymatic solution. Tips of soft meristematic tissues were squashed in $45 \%$ acetic acid. The cover slip was removed by liquid nitrogen-freezing method and the preparations were dried at room temperature.

DNA probe PCR-amplified DNA using the random primer OPB-06 (CTG CTG GGA C) obtained from the Operon-B Primer Kit (Operon, U.S.A.), was used as a probe. PCR reactions were performed in a final volume of $40 \mu 1$ containing $20 \mu 12 \mathrm{X}$ master mix ( 0.05 units/ $\mu 1$ Taq DNA polymerase in $2 \mathrm{X}$ PCR buffer $\left[4 \mathrm{mM} \mathrm{MgCl} \mathrm{Mg}_{2}\right.$ and 4dNTPs $(0.4 \mathrm{mM}$ of each)], $10 \mathrm{Pico} \mathrm{mol} / \mu \mathrm{l}$ of the primer (OPB-06) and 1ng of DNA template. The final reaction volume was completed to $40 \mu \mathrm{l}$ using sterilized distilled water. The amplifications were carried out in a thermal Cycler (Thermo Hybaid) programmed for initial preheating period in one step of $5 \mathrm{~min}$ at $94^{\circ} \mathrm{C}$ followed by 40 cycles of 3 steps (DNA denaturation at $94^{\circ} \mathrm{C}$ for 1 min, primer annealing at $36^{\circ} \mathrm{C}$ for $1 \mathrm{~min}$ and primer extension at $72^{\circ} \mathrm{C}$ for $2 \mathrm{~min}$, respectively) in each and a final subsequent cycle of post extension at $72^{\circ} \mathrm{C}$ for $5 \mathrm{~min}$. Labeling of RAPD-PCR DNA probe The probes were labeled using Prime-It ${ }^{\circledR}$ Fluor Fluorscence Labelling Kit. DNA probe was labeled by mixing $50 \mathrm{ng}$ of DNA template (PCR product) with $28 \mu 1$ of distilled water and $10 \mu 1$ of random 9-mer primers. The mixture was heated to $95^{\circ} \mathrm{C}$ for $5 \mathrm{~min}$ in water bath, then briefly centrifuged at room temperature and placed on ice. $10 \mu 1$ of reaction buffer $(8 \mu 1$ of fluor-12-dUTP $+92 \mu$ l of $5 \mathrm{X}$ nucleotide buffer) and $1 \mu \mathrm{l}(5 \mathrm{U})$ of exonuclease-free Klenow were added to the previous mixture and well mixed. The reaction mixture was incubated at $37^{\circ} \mathrm{C}$ for $30 \mathrm{~min}$. The reaction was stopped by adding $2 \mu \mathrm{l}$ of stop mix, then, stored overnight at $4{ }^{\circ} \mathrm{C}$ in the dark. Unincorporated nucleotides were removed by precipitation as follows: $1 / 10$ volume of $3 \mathrm{M}$ sodium acetate and 2.5 volumes of $100 \%(\mathrm{v} / \mathrm{v})$ cold ethanol were added to the reaction tube. The tube was incubated on ice for $20 \mathrm{~min}$ and centrifuged for $30 \mathrm{~min}$. The pellet was washed with $70 \%(\mathrm{v} / \mathrm{v})$ cold 
ethanol and then was dried in a vacuum lyophilizer. The pellet was resuspended in $10 \mu 1$ of hybridization buffer (50\% formamide and $10 \%$ dextran sulfate in $4 \mathrm{XSSC}$ buffer). Probes were preserved at $-20^{\circ} \mathrm{C}$ for use.

Chromosome denaturation The slides were denaturated in a preheated formamide solution ( $70 \%$ in $2 \mathrm{XSSC})$ at $73^{\circ} \mathrm{C}$ for $2 \mathrm{~min}$., dehydrated in an ice cold ethanol series (70, 80 snd finally $100 \%$ ) per $5 \mathrm{~min}$. each and then allowed to air-dry.

The procedure of FISH and detection of the probe The procedure of FISH and detection of the probe followed the methods described by Kondo et al. (1996) and Abd El-Twab and Kondo (2008). The probe mixtures were denaturated at $95^{\circ} \mathrm{C}$ for $10 \mathrm{~min}$., applied to appropriate slides $(15 \mu 1$ per slide) and covered with parafilm without air bubbles. The slides were then incubated in a preheated humid chamber at $37^{\circ} \mathrm{C}$ overnight of hybridization. After gently removing the parafilm covers by floating, the slides were washed $2 \times 10 \mathrm{~min}$. in $2 \mathrm{XSSC}$ at room temperature and then washed 2 X10 min. in 4XSSC and allowed to air-dry. Each slide was stained by one drop of PI $(600 \mu 1 \mathrm{PI}$ in $5 \mathrm{ml}$ glycerol). The fluorescence signals were examined with an epifluorescence microscope with Olympus BX 51 WB filter cassette (yellow-red-color), and microphotographs were taken on CCD camera (Olympus C-4040). Analysis of hybridization, signals and image was produced using Adobe Photoshop 7.

\section{RESULTS AND DISCUSSION}

Effect of different concentrations of deoxynivalenol (DON) and aflatoxin $\mathrm{B}_{1}\left(\mathrm{AFB}_{1}\right)$ mycotoxins on wheat chromosomes were previously investigated (Mohammed et al. 2008; Fadl-allah et al. 2007). The results revealed the significant effect of $25 \mu \mathrm{g} / \mathrm{ml}$ of both toxins. Fluorescence in situ hybridisation (FISH) technique opens the possibility of obtaining molecular cytogenetic results from interphase and metaphase cells. Such colorful results, which were impossible to achieve prior to the FISH technique, are easy to interpret, explain and understand (Abd El-Twab 2007; Abd El-Twab and Kondo 2008). Thus, FISH technique was used, in the present work, to detected chromosome and chromatid type aberrations microscopically in metaphase cells. PCR-amplified DNA, from the untreated plants, using the random primer OPB-06 (Fig. 1) was used as a probe. Changes of existence and physical distribution of DNA fragment detected using this primer which have been induced by $25 \mu \mathrm{g} / \mathrm{ml}$ of DON and $\mathrm{AFB}_{1}$ were investigated.

Signals of hybridized sites could be observed in both interphase and metaphase plates after hybridization with Fluor Fluorscence labeled RAPD probe and could characterize individual chromosomes in the chromosome complement of wheat (Fig. 2). Number and percentage of FISH signals in metaphase plates and interphase nuclei were counted in control plants as well as plants treated

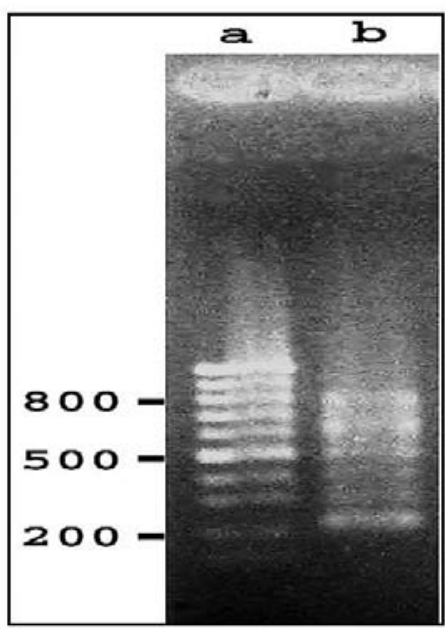

Fig. 1. RAPD-PCR pattern of wheat DNA using the random primer OPB-06 OPB (b) and $100 \mathrm{bp}$ ladder (a).
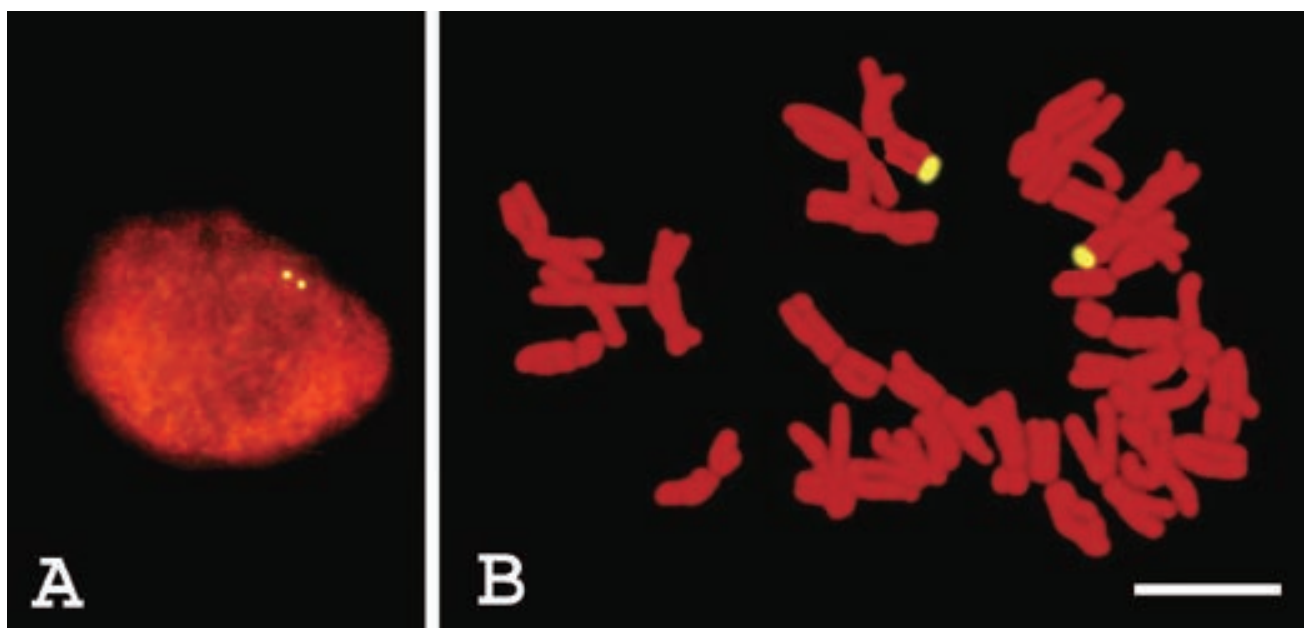

Fig. 2. FISH signals detected after using the labeled RAPD-PCR probe that hybridized with chromosomes of Triticum durum (control plant). The two yellow-colored FISH signals were adjacent in interphase nucleus (A) and were terminal loci on two metaphase chromosomes (B). $\mathrm{Bar}=10 \mu \mathrm{m}$. 
Table 1. Number and \% of FISH signals detected by RAPD probes in metaphase and interphase plates of control and treated wheat plants with toxins

\begin{tabular}{|c|c|c|c|c|c|c|c|c|}
\hline \multirow[b]{2}{*}{ Toxins } & \multicolumn{4}{|c|}{ No. of metaphase plates with } & \multicolumn{4}{|c|}{ No. of interphase nuclei with } \\
\hline & $\begin{array}{c}\text { One FISH } \\
\text { signal }\end{array}$ & $\begin{array}{c}\text { Two FISH } \\
\text { signals }\end{array}$ & $\begin{array}{c}\text { No FISH } \\
\text { signals }\end{array}$ & Total & $\begin{array}{c}\text { One FISH } \\
\text { signal }\end{array}$ & $\begin{array}{c}\text { Two FISH } \\
\text { signals }\end{array}$ & $\begin{array}{c}\text { Four FISH } \\
\text { signals }\end{array}$ & Total \\
\hline Control & $\begin{array}{c}9 \\
(21.4 \%)\end{array}$ & $\begin{array}{c}32 \\
(76.2 \%)\end{array}$ & $\begin{array}{c}1 \\
(2.4 \%)\end{array}$ & 42 & $\begin{array}{c}25 \\
(23.6 \%)\end{array}$ & $\begin{array}{c}66 \\
(62.3 \%)\end{array}$ & $\begin{array}{c}15 \\
(14.2 \%)\end{array}$ & 106 \\
\hline AF B1 & $\begin{array}{c}1 \\
(3.6 \%)\end{array}$ & $\begin{array}{c}2 \\
(7.1 \%)\end{array}$ & $\begin{array}{c}25 \\
(89.3 \%)\end{array}$ & 28 & $\begin{array}{c}32 \\
(42.1 \%)\end{array}$ & $\begin{array}{c}44 \\
(57.8 \%)\end{array}$ & - & 76 \\
\hline DON & $\begin{array}{c}3 \\
(10.7 \%)\end{array}$ & $\begin{array}{c}1 \\
(3.6 \%)\end{array}$ & $\begin{array}{c}24 \\
(85.7 \%)\end{array}$ & 28 & $\begin{array}{c}49 \\
(44.1 \%)\end{array}$ & $\begin{array}{c}59 \\
(53.2 \%)\end{array}$ & $\begin{array}{c}3 \\
(2.7 \%)\end{array}$ & 111 \\
\hline
\end{tabular}

with the two investigated toxins (Table 1). The FISH signals of the RAPD sites of metaphase chromosomes were confirmed as two yellow-color signals at interphase of the control plates.

Regarding the control cells, 42 metaphase plates were counted. $21.4 \%$ of them exhibited one terminal signals, while $76.2 \%$ of plates reveal two terminal signals and no signals were observed on chromosomes of $2.4 \%$ of the counted metaphase plates. Strong clear signals were distributed in 106 interphase plates. Out of these plates, $23.6 \%$ had one signal whereas $62.3 \%$ exhibited two signals and four signals were observed in $14.2 \%$ of interphase nuclei.

Table 1 showed the number and distribution of FISH signals of DNA sites which hybridized with fluorscence labeled RAPD probe in plants treated with $\mathrm{AFB}_{1}$. Yellow signals were observed mostly in the interphase nuclei while they were very rare in metaphase plates. Twentyeight metaphase plates were counted in plants treated with $\mathrm{AFB}_{1}, 3.6 \%$ of them had one terminal signal while $7.1 \%$ revealed two signals and no signals were observed in $89.3 \%$ of the counted metaphase plates. Regarding the interphase nuclei, 76 plates were counted in plants treated with $\mathrm{AFB}_{1}$. Only one signal was observed in $42.1 \%$ of the plates whereas two signals were observed in $57.8 \%$ interphase plates of them.

The number and distribution of FISH signals of DNA sites, hybridized with the same probe, in plants treated with DON are also shown in Table 1. FISH signals were observed only in four metaphase-plates among the 28 counted plates. $10.7 \%$ metaphase plates exhibited one terminal signal, while 3.6\% metaphase plates exhibited two signals, and the other $85.7 \%$ metaphase plates exhibited no signal. Clear FISH signals were distributed in 111 interphase nuclei counted as follows: $44.1 \%$ of them had one signal, and $53.2 \%$ had two signals, and $2.7 \%$ had four signals .

FISH could be useful to detect mutations such as translocations that are barely detectable with conventional methods (Abd El-Twab and Kondo 2007). Disappearance of FISH signals in metaphase plates of plants treated with toxins as compared to control plants indicates misshybridization (annealing) of the fluorscence labeled RAPD-PCR probe with the complementary DNA sequence of wheat genome.

DNA changes could be represented as retrotransposons which are mobile genetic elements found throughout the plant kingdom (Fedoroff 2000; Boeke and Corces 1989). Rocha et al. (2005) found three mRNA transcript fragments, over expressed in wheat roots treated with DON, with full or partial homology to retrotransposons. This and other researches (Ivashuta et al. 2002) implies the possibility of genetic or epigenetic transposon activation in plant cells in response to stress. Therefore, Fadl-Allah et al. (2007) and Mohammed et al. (2008) speculated that the existed variation of DNA which have been detected by RAPD-PCR after treating with DON and $\mathrm{AFB}_{1}$ might be a DNA structural changes, which indicated their genotoxic effect on wheat.

It was found that toxicants evoke organ dysfunction and tissue injury by interfering with normal gene regulation. Genotoxic agents cause primary DNA lesions; e.g., formation of DNA adducts, oxidation of bases, basedimerization or cross links), which are either repaired or otherwise lead to irreversible alterations of the DNA (Schiestl 1989; Ramel et al. 1996). Therefore, toxicants were speculated to mediate their effects by (1) overlapping DNA target sites, (2) masking critical domains and/or (3) altering their native conformation (Kannabiran et al. 1997; Ye and Young 1997). Thus, using $\mathrm{DON}$ and $\mathrm{AFB}_{1}$ may cause physical and reorganization changes in the DNA altering native conformation, which may explain the disappearance of the yellow signals of the RAPD-FISH sites from the metaphase chromosomes and detecting them in the interphase nuclei after using the labeled RAPD probe.

Alterations occurred on micronuclei induction as well as structural chromosomal aberrations induced by DON and $\mathrm{AFB}_{1}$ were previously detected on meiotic chromosomes of wheat by Mohammed et al. (2008) and Fadl-Allah et al. (2007). They also detected considerable variation of the RAPD-PCR fragments of plants treated 
with $\mathrm{DON}$ and $\mathrm{AFB}_{1}$ indicating the effect of this toxins on the DNA level. The disappearance of the FISH signals of the RAPD loci in the metaphase chromosomes, in the present work, might confirm the effect of such toxins on the gene level (gene mutations). In general, such data might lend us support to speculate and confirm that the disappearance of the RAPD-PCR fragments in gel-electrophoresis and FISH signals in metaphase chromosomes after treatment with DON and AFB1 mycotoxins might resulted due to overlapping, masking critical domains and/or altering DNA native conformation sites, which prevent the RAPD sites to be amplified in PCR and the hybridization of the RAPD probe on metaphase chromosomes. In conclusion, the currently available data demonstrate the genotoxic effect of DON and $\mathrm{AFB}_{1}$ on wheat.

When the improvements in cytogenetic techniques seemed to have reached a plateau, a combination of cytogenetics and molecular biology gave rise to FISH, opening many new opportunities in the field. Once an appropriately labeled DNA probe is available, FISH becomes the technique of choice. The method of FISH used here was effective in identifying the RAPD markers that could differentiate individual RAPD-bearing chromosomes. The RAPD FISH would be a simple and effective way to characterize diverse collections of germplasm materials correctly. Further study might be applied on the chromosomes of the tetra- and hexaamphiploid varieties in comparison with their diploid ancestors. Using the probes of RAPD-PCR FISH markers might increase our knowledge about the genome characterization and differentiation after stress with mycotoxicants.

ACKNOWLEDGEMENTS. The authors are grateful to Prof. Dr. A. M. Ata for his technical assistance and sincere help.

\section{LiTERATURE CiTED}

Abd El-Twab, M. H. 2007. Physical mapping of the 45S rDNA on the chromosomes of Triticum turgidum and $T$. aestivum using fluorescence in situ hybridization for chro mosome ancestors. Arab Journ. Biotech. 10: 69-80.

Abd El-Twab, M. H. and Kondo, K. 2000. Discrimination and isolation of terminal chromosomal regions of Dendranthema occidentali-japonense in the chromosomes of F1 hybrid between D. occidentali-japonense and $D$. boreale by using GISH. Chrom. Sci. 4: 87-93

Abd El-Twab, M. H. and Kondo, K. 2007. FISH physical mapping of $5 \mathrm{~S}$ rDNA and telomere sequence repeats identified a peculiar chromosome mapping and mutation in Leucanthemella linearis and Nipponanthemum nipponicum in Chrysanthemum sensu lato. Chrom. Bot. 2: $11-17$.

Abd El-Twab, M. H. and Kondo, K. 2008. Identification of genomic relationships in allotetraploid hybrids between Chrysanthemum lavandulifolium X Ch. chanetii by FISH and GISH. Chrom. Bot. 3: 19-25.

Badr, A., Fadl-Allah, E. M., Mohamed, M. and Helmy, R. K. 2002. Studies on cytological effects of deoxynivalenol (DON) in wheat (Triticum aestivum L). Bull. Fac. Sci.,
Assiut Univ. 31(1-D), pp. 319-326.

Beasley, V. R. Ed. 1989. Trichothecene mycotoxicosis: pathophysiologic effects, vol. I. CRC Press, Boca Raton, Fla.

Boeke, J. D. and Corces, V. G. 1989. Transcription and reverse transcription of retrotransposons. Annual Review Microbiol. 43: 403-434.

Busby, W. F. and Wogan, G. N. 1984. Aflatoxins. Chem. Carcinogen. 2: 965-1136.

El-Naghy, M. A., Mazen, M. B. and Fadl-Allah, E. M. 1991. Production of aflatoxin B2 by Aspergillus flavus Link isolated from stored cotton seeds with different substrates. World J. Appl. Microbiol. Biotechnol. 7: 67-71.

El-Naghy, M. A., Fadl-Allah, E. M. and Samhan, M. 1999. Effect of aflatoxin G1 on germination, growth and metabolic activities of some crop plants. Cytobios. 97: 87-93.

Fadl-Allah, E. M. 1987. Studies on the effect of some mycotoxins on plant growth and cell ultrastructure. $\mathrm{Ph}$. D. Thesis, Botany Department, Faculty of Science, Minia University, Minia, Egypt.

Fadl-Allah, E. M. and Abd El-Rahim, A. T. 1991. The effect of three mycotoxins on mitotic division and somatic chromosomes of roots of Allium cepa. Bull. Fac. Sci. Assiut Univ. 20: 101-111.

Fadl-Allah, E. M. 1998. Occurrence and toxigenicity of Fusarium moniliforme from freshly harvested maize ears with special reference to fumonisin production in Egypt. Mycopathologia. 140: 99-103.

Fadl-Allah, E. M., Mahmoud, M. A. H. and Helmey, R. K. 2007. Genotoxic effect of Aflatoxin $B_{1}$ on 5 S rDNA gene and meiotic chromosomes of wheat. African Crop Science Conference Proceedings. Vol. 8. pp. 683-691.

Fedoroff, N. 2000. How jumping genes were discovered. Nature Structural Biology. 8: 300-301.

Feinberg, B. and McLaughlin, C. S. 1989. Biochemical mechanism of Action of trichothecene mycotoxins,. In V. R. Beasley (ed.),Trichothecene mycotoxicoses : pathophysiologic effects. Vol.I. CRC Press, Boca Raton, Fla., pp.27-35.

Grove, J. F. 1993. Macrocyclic Trichothecenes. Nat. Prod. Rep. 10: 429-448.

Grove, J. F. 1996. Non-macrocyclic trichothecenes. Part 2. Prog. Chem. Org. Nat. Prod. 69: 1-70.

Harrison, G. E. and Heslop-Harrison, J. S. 1995. centromeric repetitive DNA sequences in the genus Brassica.Theor. Appl. Genet. 90:157-165.

Hocking, A. D., Pitt, J. I., Samson, R. A. and Thrane, U. 2006. Advances in Food Mycology. Section 3. Springer US.

Ivashuta, S., Naumkina, M., Gau, M., Uchiyama, K., Isobe, S., Mizukami, Y. and Shimamoto, Y. 2002. Genotypedependent transcriptional activation of novel repetitive elements during cold acclimation of alfalfa (Medicago sativa). Plant Jour. 31: 615-627.

Jiang, J. and Gill, B. S. 1994. Different species-specific chromosome translocations in Triticum timopheevii and T. turgidum support the diphyletic origin of polyploidy wheats. Chrom. Res. 2: 59-64.

Joffe, A. Z. 1986. Fusarium species: their biology and toxicology. JohnWiley and Sons, New York, N. Y.

Kannabiran, C., Zeng, X., Vales, L. D. 1997. The mammalian transcriptional repressor $\mathrm{RBP}(\mathrm{CBF} 1)$ regulates interleukin-6 gene expression. Mol. Cell. Biol. 17: 1-9.

Kondo, K., Honda, Y. and Tanaka, R. 1996. Chromosome marking in Dendranthema japonica var. wakasaense and its closely related species by fluorescence in situ hybridization using rDNA probe. La Kromosomo. II-81: 2785-2791.

Mahmoud, M. A. H, Fadl-Allah, E. M., Abd El-Twab, M. H. and Helmey, R. K. 2008. Molecular and cytological effects of Deoxynivalenol Mycotoxin (DON) in wheat 
(Triticum vulgaris) using RAPD- PCR Analysis. Chrom. Bot. 3: 31-39.

Marasas, W. F. O., Nelson, P. E. and Toussoun, T. A. 1984. Toxigenic Fusarium species: identity and mycotoxicology. The Pennsylvania State University Press, University Park, $\mathrm{Pa}$.

Masood, A.; Rahman, M. F. and Bilgrami, K. S. 1993. Cytotoxic effects of DON and T-2 toxins on plant cells. Mycopath. 124: 95-97.

McLaughlin, C. S., Vaughan, M. H., Campbell, I. M., Wei, C. M., Stafford, M. E. and Hansen, B. S. 1977. Inhibition of protein synthesis by trichothecenes. In: Rodericks J V, Hesseltine C W, Mehlman M A, Eds.: Mycotoxins in human and health. Park Forest South, I L: Patho tox. pp 263-275.

Miller, J. D., ApSimon, J. W., Blackwell, B. A., Greenhalgh, R. and Taylor, A. 2001. Deoxynivalenol: a 25 year perspective on a trichothecene of agricultural importance. In: B. A. Summerell, J. F. Leslie, D. Back-house, W. L. Bryden, and L. W. Burgess Eds., Fusarium, Paul E. Nelson Memorial Symposium. APS Press, St. Paul, Minn, pp.310-319.

Minto, R. E., and Townsend, C. A. 1997. Enzymology and molecular biology of aflatoxin biosynthesis. Chem. Rev. 97: 2537-2555.

Packa, D. 1991. Cytogenetic changes in plant cells as influenced by mycotoxins. Mycotoxin Res. 7: 150-155.

Ramel, C., H. Cederberg, J. Magnusson, J. Vogel, A. T., Natarajan H. Mullender, H., Nivard, J. M., Parry, J. M., Leyson, A., Comendador, M. A., Sierra, L. M., Ferreiro, J. A. and Consuegra, S. 1996. Somatic recombination, gene amplification and cancer. Mutation Res. 353: 85107.

Robens, J. F. and Richard, J. L. 1992. Aflatoxins in animal and human health. Rev. Environ. Contam. Toxicol. 127: 69-94.

Rocha, O., Ansari, K. and Doohan, F. M. 2005. Effects of trichothecene mycotoxins on eukaryotic cells: A review. Food Additives Contam. 22: 369-378.

Schiestl, R. H. 1989. Nonmutagenic mutagen induced intrachromosomal recombination in yeast. Nature 337: 285-288.

Shen, H. M. and Ong, C. N. 1996. Mutations of the p53 tumor suppressor gene and ras oncogenes in aflatoxin hepatocarcinogenesis. Mutation Res. 366: 23-44

Scott, P. M. 1989. The natural occurrence of trichothecenes,. In: V. H. Beasley Ed., Trichothecene mycotoxicosis: pathophysiologic effects. vol. I. C RC Press, Boca Raton, Fla. pp.1-26.

Squire, R. A. 1981. Ranking animal carcinogens: a proposed regulatory approach. Science 214: 877-880.

Stafford, M. E. and McLaughlin, C. S. 1973. Trichodermin, apossible inhibitor of the termination process of protein synthesis. J. Cell Physiol. 82: 121-124.

Thompson, W. L. and Wannemacher, R. W. Jr. 1990. In vivo effects of T-2 toxin on synthesis of proteins and DNA in rat tissues. Toxicol. Appl. Pharmacol. 105: 482-491.

Ueno, Y. 1983. Trichothecenes: chemical, biological and toxicological aspects. Elsevier, New York. (Y. Ueno, Ed.) pp.135-146.

Wei, C. M., Campbell, I. M., McLaughlin, C. S. and Vaughn, M. H. 1974. Binding of trichodermin to mammalian ribosomes and its inhibition by other 12,13-epoxytrichothecenes. Mol. Cell Biochem. 3: 215-219.

Wogan, G. N. 1992. Aflatoxins as risk factors for hepatocellular Carcinoma in humans. Cancer Res. 52: 2114-2118.

Ye, J. and Young, H. A. 1997. Negative regulation of cytokine gene transcription. FASEBJ. 11: 825-833 